Simone Osthoff *

\title{
Art \& Design Education Centered Around Democratic and Disruptive Practices
}

Simone Osthoff é professora de Estudos Críticos na Escola de Artes Visuais da Pennsylvania State University. Nascida no Brasil e vivendo nos EUA, sua pesquisa enfoca práticas e histórias de arte experimental e decolonial. Entre as várias publicações está o livro Performing the Archive: The Transformation of the Archive in Contemporary Art de um Repositório de Documentos para o Meio Arte. <sxo11@psu.edu>
Abstract This article emphasizes approaches to design which are centered on democratic and disruptive practices. By focusing on artists and designers who embrace a critical edge of the discipline, it begins describing a few themes explored in the symposium Matters of Art \& Design Education (MADE), at the Pennsylvania State University, and examines some of the theoretical horizons they point to. In the second part of the article, the author interviews the artist and designer Carlos Rosas, who helped develop, and is currently the Professsor in Charge of the IDS-Interdisciplinary Digital Studio program, a Bachelor of Design (B.Des) program in the School of Visual Arts, at that prestigious research University.

Keywords Pennsylvania State University, Latin America, Carlos Rosas, Disruption, Obsolescence.

\section{Arte e Design Educação Centrada em Práticas Democráticas e Disruptivas}

Resumo Este artigo enfatiza abordagens de design centradas em práticas democráticas e disruptivas. Ao concentrar-se em artistas e designers que adotam uma linha crítica da disciplina, começa a descrever alguns temas explorados no simpósio Matérias de Educação em Arte e Design (MADE), na Pennsylvania State University, e examina alguns dos horizontes teóricos que eles apontam. Na segunda parte do artigo, o autor entrevista o artista e designer Carlos Rosas, que ajudou a desenvolver, e atualmente é o Professor Responsável pelo programa IDS - Interdisciplinary Digital Studio, um programa de Bacharelado em Design (B.Des) na Escola de Artes Visuais, naquela pretigiosa universidade de pesquisa.

Palavras chave Universidade Estadual da Pensilvânia. América Latina. Carlos Rosas Ruptura. Obsolescência. 
The growing prominence of Design-related thinking in higher education was the motivation for the symposium Matters of Art \& Design Education (MADE), which took place in the Arts and Design Research Incubator-ADRI-at the Pennsylvania State University, in the Spring of 2018. The symposium furthered ADRI's goal of exploring the meaning of design with a big D, an umbrella term that connects research across the College with Colleges throughout Penn State and beyond. In sum, it examined how research in Arts and Architecture fits in, and can further be aligned with, the vast research opportunities of an R1 University (research universities with the highest research activity). The faculty presentations explored design as an interdisciplinary set of methodologies and modes of learning centered on project-based inquiry with a deep investment in making. Thematic threads included design for all, maker culture, universal design, cultural preservation, ecological sustainability, spatial literacy, social practice and participatory frameworks.

This article emphasizes the approaches to design centered on democratic and disruptive practices, by focusing on artists and designers who embrace the more critical edge of their disciplines. To this end, I will describe a few presentations, examine ideas and theoretical horizons they point to, and conclude with a detailed interview with one of the presenters, the artist and designer Carlos Rosas (Chile/United States). Rosas helped develop, and is currently the Professsor in Charge of the IDS-Interdisciplinary Digital Studio program, a Bachelor of Design (B.Des) program in the School of Visual Arts, currently changing its name to Digital Arts and Media Design (DART).

Short presentations followed by engaging discussions delineated experiences of making, as well as a few distinct ideological and philosophical approaches to design education. Some presentations were centered around skills, emphasizing the need to meet the requirements of the programs accreditation. Others emphasized critical thinking and issues of social equity, pointing to a growing diversity of values and cultures among students and faculty.

\section{Design with a Democratically Oriented Focus}

Approaches to design in the symposium varied not just according to disciplines, but also reflected different cultural experiences. Early in the day, Rosas spoke about the importance of having art and design students work in collaborative studio environment, and he presented a class project developed over one semester: the game "Mine Avoiders."

This game, envisioned by the Bosnian Kenan Zekic, a Penn State visiting scholar from the International University of Sarajevo, was designed to improve school children's awareness of still-buried landmines while also building technology literacy with augmented-reality and coding concepts. The challenging project was successfully developed by students in the 
AA310 Creative Collaboration Studio course co-taught by Rosas and Andrew Hieronymi (Switzerland/United States), a professor of interactive scripting and programing. The students combined the important core idea with 3D skills, programing, flow chart, and music/sound design.

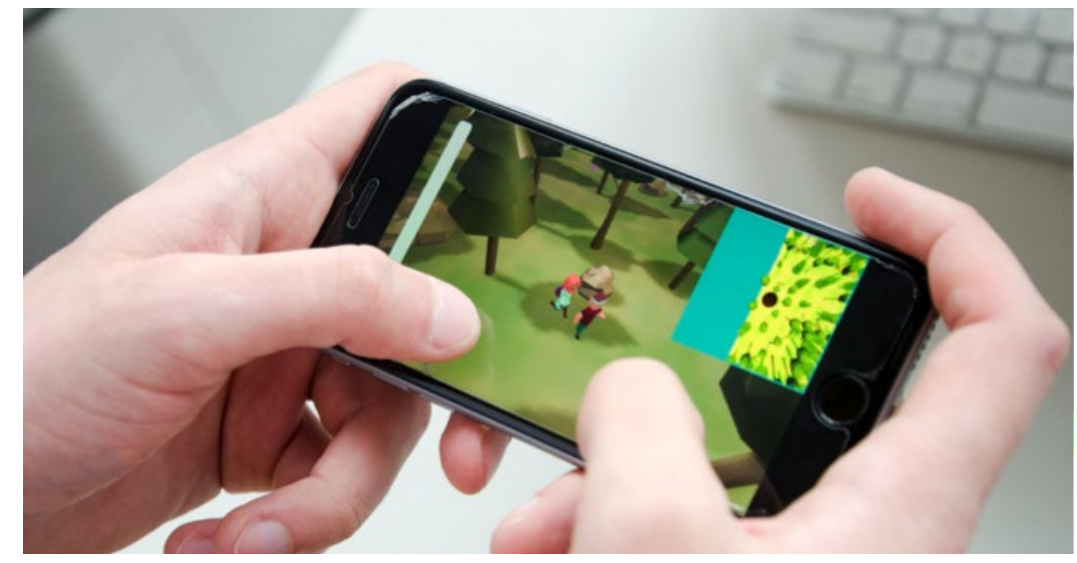

Fig 1. Penn State students in game design helped develop a digital game that would improve school children's awareness of still-buried landmines while also building technology literacy with augmented-reality and coding concepts, in countries like Bosnia, Herzegovina, Afghanistan, Angola and Cambodia.

Image: Courtesy of the Penn State School of Visual Arts

A comparable socially concerned perspective came from architect and urban planner Malika Bose (India/United States), who spoke of collaborative design by emphasizing notions of democracy and therefore of working with diverse populations, often marginalized and without a say in urban projects which impact them directly. Malika approaches design as democratic practice, understanding design as aspiration, tied to issues of justice and fairness. According to her, architects have responsibility towards a democratic professionalization. Her arguments contrast with the more competitive neoliberal approach to architecture.

While exploring the importance of integrating making in the design process - the ability to think through materials and to problem solve, architect Benay Gürsoy Toykoç (Turkey/United States), who came to Penn State from the Architectural Design Computing Program at Istanbul Technical University, argued for the importance of designing with, nor for. Beginning at the foundation level design courses, she encourages students to "hack" technology, in addition to using open source programs. Benay noted that it is important to learn with the students not just teach them, and to create an enjoyable culture of being in the studio, reminding us that traditionally, the architecture studio has been hostile to women, minorities, and families. Under the traditional model of architecture, being successful means being tough, suffering, not sleeping, and having no time for anything else. 
Fig 2. Benay Gürsoy Toykoç's students building a 3D Ceramic Printer and 3D printed works of students

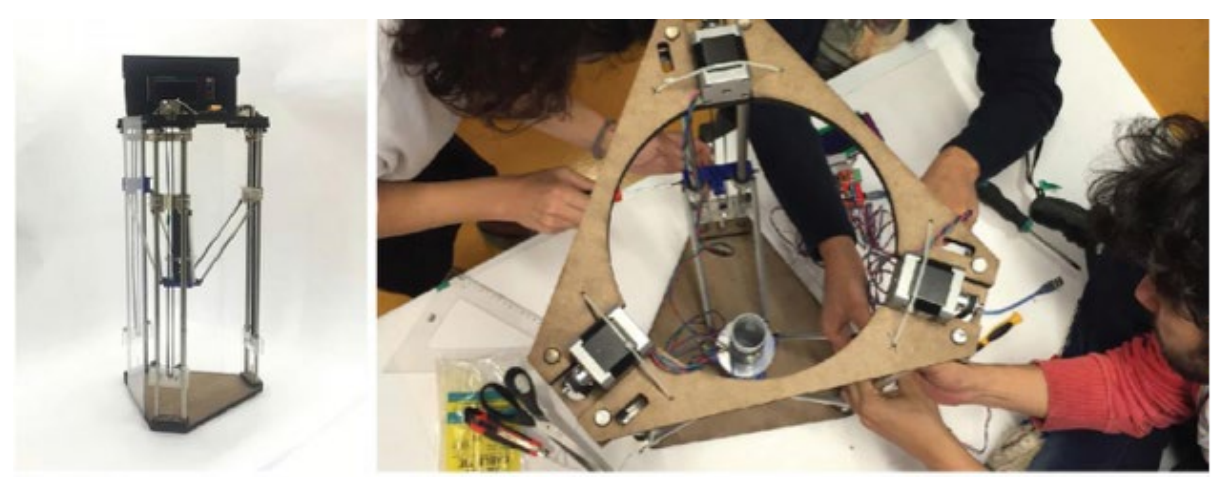

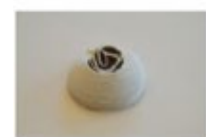
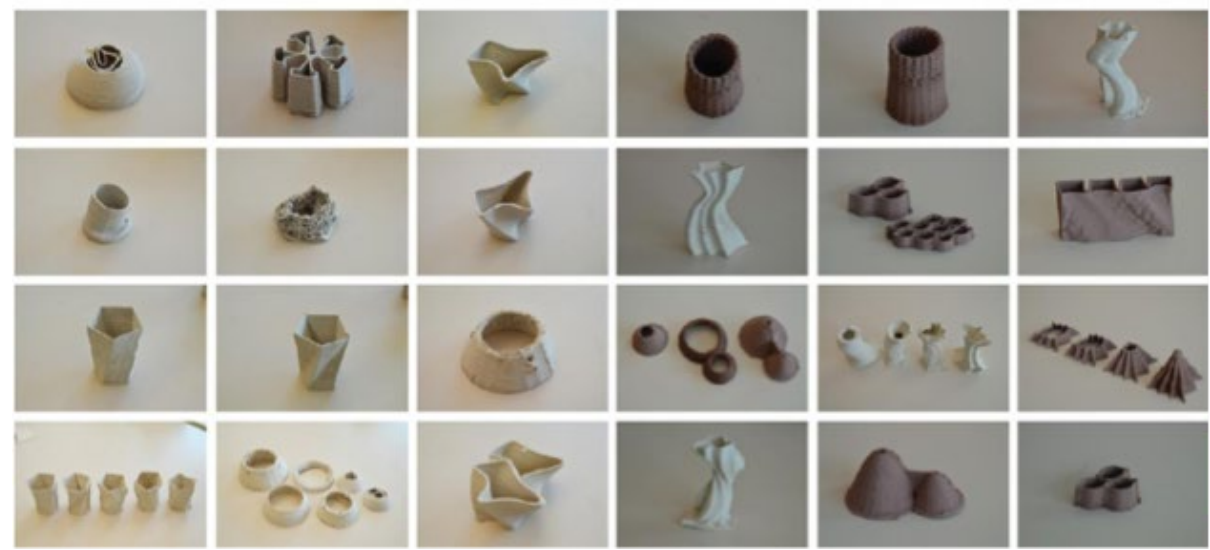

Benay's demystification of expertise brought to mind the arguments of the French theorist Jacques Ranciére in an early book, The Ignorant Schoolmaster: Five Lessons in Intellectual Emancipation. He argued that the expert is not the one who knows, but the one who asks questions, urging students to find out information and to teach themselves how to learn. Different modes of thinking and teaching-how do we know what we know? What do we learn and how?-pointed to how fast, apparently simple questions, involve complex philosophical, pedagogical, and ideological matters both in design and education.

\section{Other Ways of Knowing}

In the Summer 2018 issue of Art Journal, an activist and provocative article written by Zach Kaiser, titled "Citation Bombing: Tactical and Symbolic Subversion of Academic Metrification," proposed to disrupt the algorithmic dominance of Goggle Scholar in academia, at least symbolically, by combining humor and a subversive strategy. Elsewhere in the article/ manifesto, Kaiser mentioned three different trends in American education by way of David Labaree's "Public Goods, Private Goods: The American Struggle over Educational Goals." It is worth reproducing this footnote in its entirety for its summary of the history of education in the United States: 
Disagreement," as he reflects upon "glocality"-the ability to function locally with a global awareness-versus locality in Latin-American. He references Marc Augé, 1992 book, Non-places, Introduction to an Anthropology of Supermodernity, and extends Augé's central concept, from non-places (transnational corporations such as the Hilton hotels, Holiday Inn, Starbucks, and McDonalds) to online spaces. One of the artists Navas selected for the biennial in Mexico City was Carlos Rosas, whose approach to issues of place and location emphasizes the mediation of networks and digital systems. Navas writes:

The aesthetic of networked culture in terms of supermodernity is directly expressed in the work of Carlos Rosas as forms of abstraction. GPS Pallet Series: (Coordinate) Paintings/I think I Got IKEA'd Project; Bulls on Parade: Protest Remixes; as well as Step and Repeat Cycles: Live/Networked Installation and Remixed Sessions, expose how location can become abstracted in terms of painting or sound, while still providing a sense of concreteness by mere citation of places as concepts.

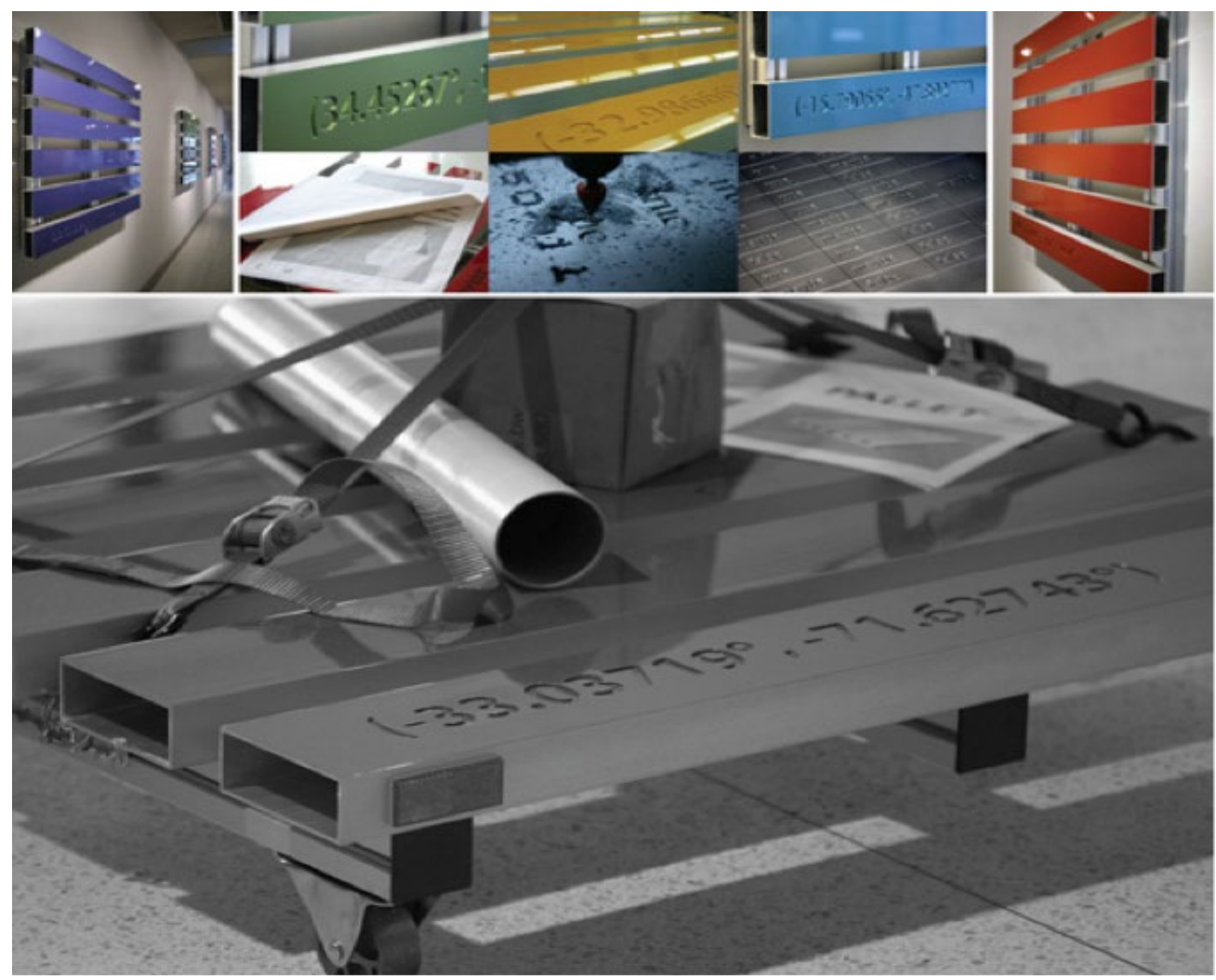

Fig 4. GPS Pallet Series: (Coordinate) Paintings/I think I Got IKEA'd. An on-going series of custom fabricated pallets with color matched automotive paint (sampled on location at various coordinates) on CNC machined aluminum panels.

Photo: courtesy of the artist 


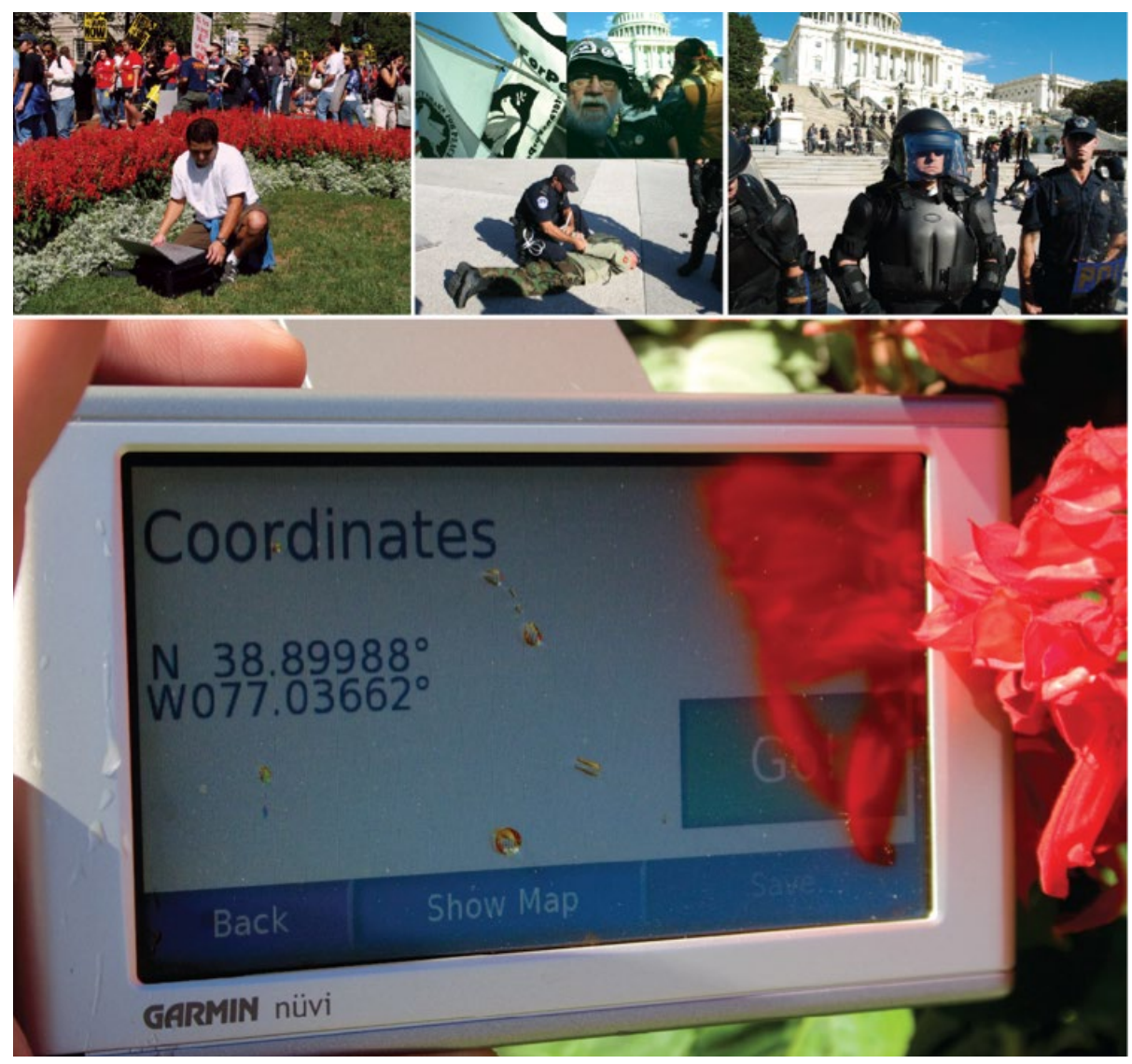

Fig 5. Coordinate

Photo: courtesy of the artist

In Rosas work, boundaries between art and design are irrelevant. In order to better understand the ideas that drive his work, after the ADRI symposium, I asked Rosas a few questions about his background and trajectory, both at Penn State and before he began working there in 2001.

\section{Design and Disruption: Carlos Rosas' formative memories}

We began talking about migration. His awareness of the issue is connected to his family history, as well as key historical events in Chile, where he spent his early childhood. Rosas explained that his general attitude towards art and design goes back to the formative memories which have played an influential role in his interests in critical theory, art history, and ultimately in his focus upon print and media authoring, design, and media publishing, as modalities for his creative practices. He concluded that an acute sense of skepticism for systems and ideologies was instilled in him at an early age, largely in response to childhood experiences and memories formed during the Chilean coup d'état in 1973, when the violent regime change led his family to emigrate from Chile to the U.S. in 1973, leaving a lasting impression on him. He became very aware of how frag- 
ile order could be and how quickly normal interactions, communications, and services could break down and more importantly, how easily media could be used as a controlling mechanism to confound, disrupt, and control through sustained and targeted messaging (propaganda).

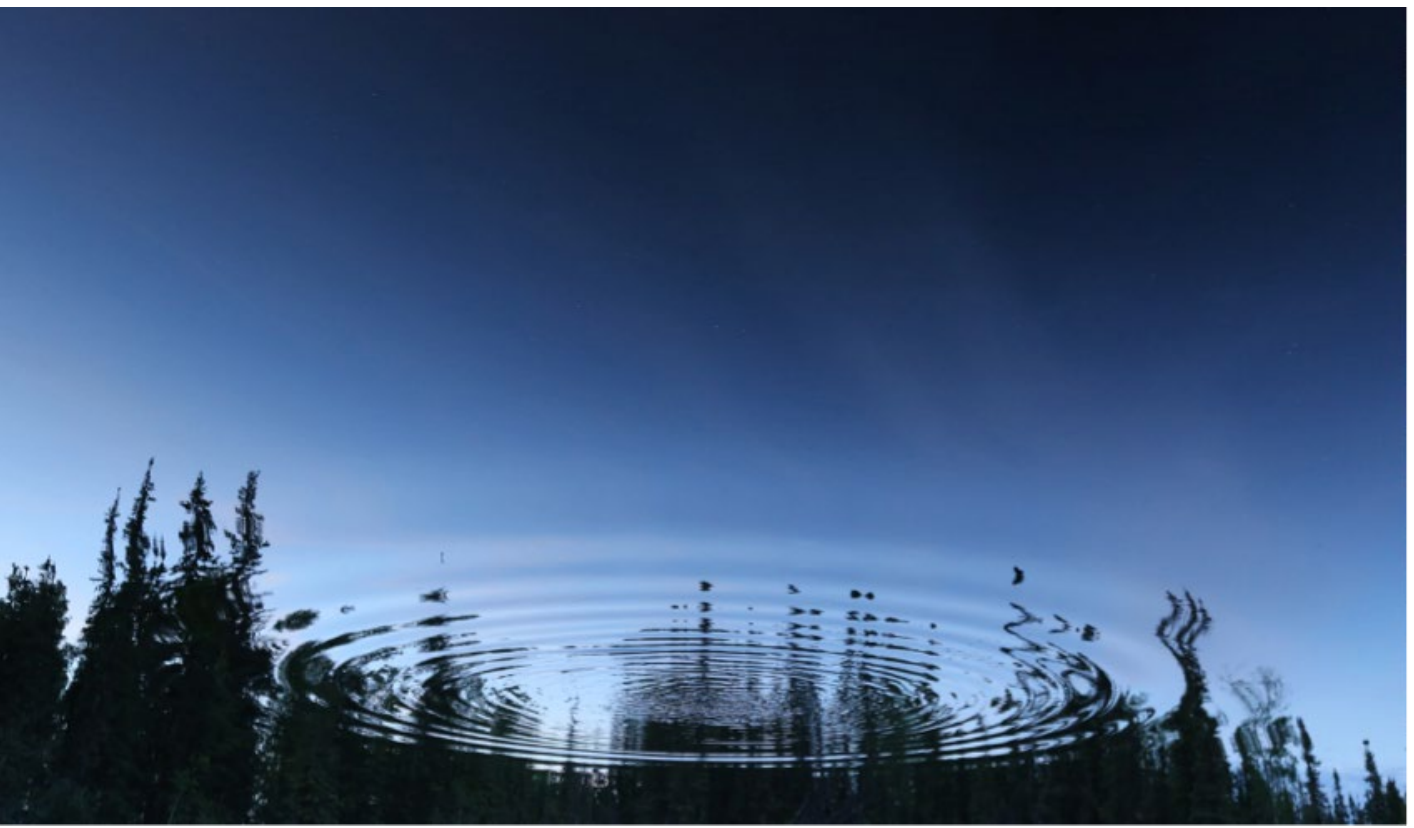

Fig 6. Carlos Rosas, Alaska Cycle, 2017

Photo: courtesy of the artist

Rosas grew up in various parts of the U.S. from Brooklyn to Alaska, from Arizona (where he got dual degrees in art history and studio) to Michigan (MFA at Cranbrook Academy of the Arts), and from California, where at CalArts, his practice as artist and designer were further combined, to Penn State and Philadelphia, where he is currently based. He still goes to Alaska from time to time to sample material for projects in remote areas. After all, it was there that he began his intimate relationship with computers and the practice of breaking programs. In Fairbanks he began studying art and computer graphics while majoring in engineering and discovered he had a skill for "making computers crash":

In Alaska, I got the opportunity to work with remote automated weather stations (RAWS) run by the U.S. Forest Service (USFS) and Bureau of Land Management (BLM). They would set up portable remote satellite weather stations to check weather patterns for firefighting or monitoring for environmental disasters like the Exxon Valdez oil spill that had recently occurred in the Prince William Sound. I worked with them as a summer internship gig and did a bunch of testing of some of their early weather monitoring system. I became really good at misusing the interface and 
accidently making things glitch, so they asked me to try to continue doing that as they developed the system and I did that for a portion of my summer, basically becoming a beta tester. I had always enjoyed breaking things, taking things apart, tinkering and putting things back together again, so this was a good time. It wasn't until later that I began to think that I was good at figuring out how things work by looking under the hood, by essentially "hacking," and in some instances, altering or customizing things for my own purposes, making them my own in some way. I tend to learn "a la Chilena"-doing things or problem solving with very little resources or actual training. As a teen, I would spend my time (and most of my money) working on my muscle car, a 1973340 Barracuda, that I would drive on weekdays and drag race on the weekends-I spent countless hours rebuilding carburetors, transmissions, and engines. Eventually, in college I studied lithography and printmaking processes, largely because it was technical and usually very procedural. I was always very process oriented, but after I know how to do something well, I kind of drop the mike and move on to the next thing that interests me.

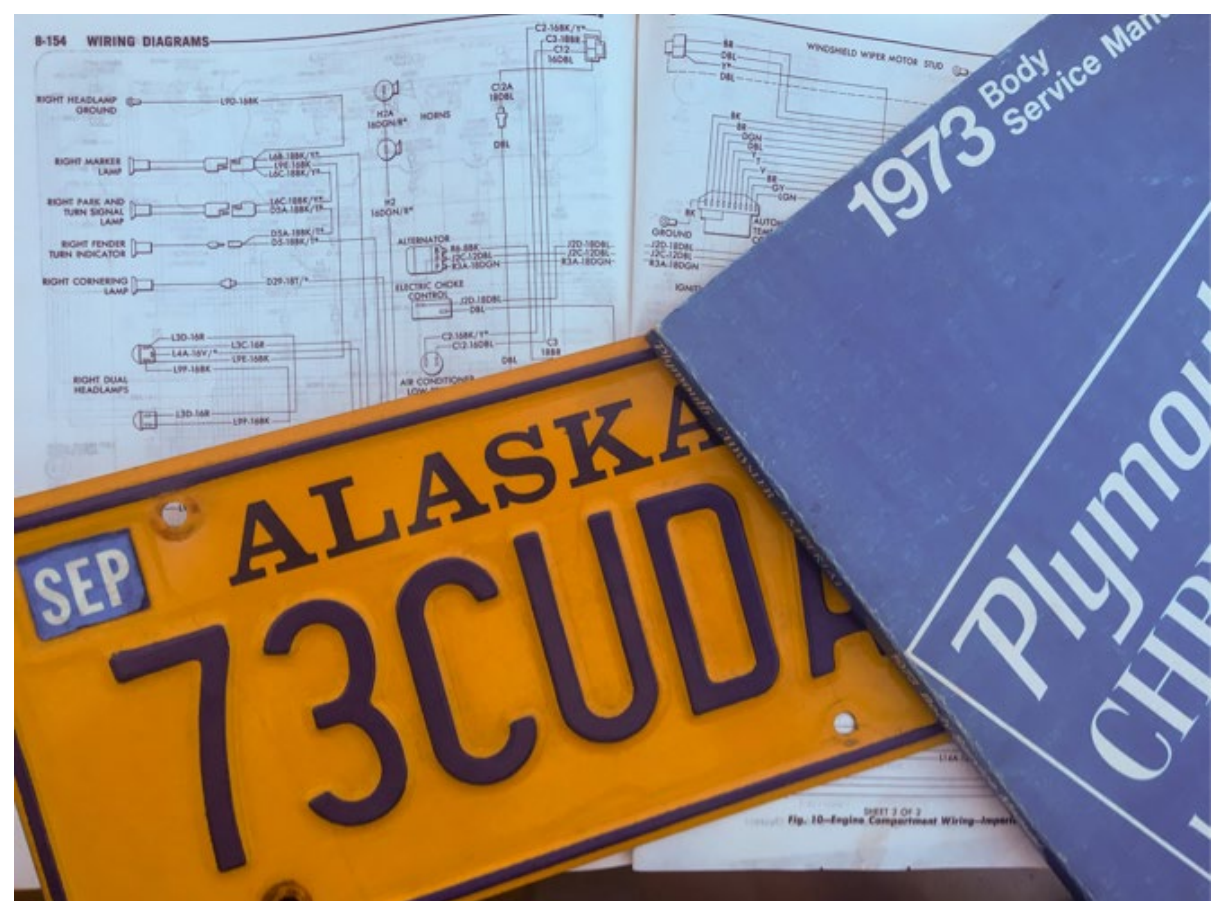

Fig 7. Carlos Rosas muscle car, a 1973340 Barracuda, which he fixed, drove, and raced with Photo: courtesy of the artist

Rosas received his MFA from the legendary Cranbrook Academy of Art, known as the cradle of American Modernism, located in Michigan, outside Detroit. In the postmodern 90s, he studied the history of industrial design, graphic design, and print media. 
I went to Cranbrook when the print media program was directed by Steve Murakishi and he was recruiting people interested in installations, contemporary culture, that kind of sensibility. Hasan Elahi and myself are part of that Cranbrook generation. We shared the building and often worked closely with the $2 \mathrm{~d}$ and $3 \mathrm{~d}$ designers (upstairs) often spending late nights in the studio silkscreening and preparing work for critiques. At the time, Katherine and Michael McCoy were the Artists in Residence where Katherine led the graphic design program, and Michael led the industrial design program. The Cranbrook design program and its postmodern poster history become legendary. That was where I got that bug and became engaged with that legacy [Rosas has a large archive of posters from the 80 s and 90 s].

After his MFA, Rosas came to CalArts to help re-envision the G-Lab (graphics lab). At the time, print media was not yet digital but existed in an experimental and conceptual expanded field. During his time in California, he participated in crazy performances and embraced an iconoclast approach to media and design: aggressive, in your face, not nice, disruptive. In Los Angeles, he went on exploring experimental sound, the web, new media publishing and authoring.

When I arrived at CalArts they were reconsidering their graphics lab, which had largely functioned under the design program. The school had largely moved away from traditional print media like etching, lithography, and none of the processes had been digitally integrated yet. I went there to help turn it into a more viable and dynamic space, and it turned out that the graphic design program had actually transferred control of the graphics lab to the art program. They brought me in as a tie between studio art and design. I understood the tradition the designers were working under (there was a strong Cranbrook Design presence among the faculty, such as Ed Fella, Jeff Keedy, Caryn Aono, Lorraine Wild), while also having a pretty considerable experience in digital imaging and pre-press, print media, printmaking, lithography, and photography.

While teaching at CalArts between 1995-2001, Rosas had the opportunity to engage with and befriend the artist Allan Sekula (1951-2013), whose work frequently focused on large economic systems, or "the imaginary and material geographies of the advanced capitalist world." He remembered the time when Sekula had just published his Fish Story, a work that soon came to both inspire and influence his own creative and critical practice, as it touched on many themes Rosas continues to explore ideas based on economies of scale and what he perceives to be "digital myths" on lossless translations/transactions and the promise of efficiency and expe- 
diency by way of technology. His Step and Repeat based works (remix-based) and resulting collaborations and performances have direct ties to conversations and musings he carried out with Allan Sekula and his long-time collaborator Robert Dansby: "discussions of labor, the effects of globalization on labor, and the telltale signs of economic squeeze on communities and locations." These ideas developed and were reinforced by a seamless practice as an artist and designer:

In California, I got deeper into design and immediately into interactive media, multimedia, cd-roms and dvd authoring and publishing, interactive installations, then eventually during the .com boom, I was heavily into website design and interactive Flash development; I was doing a lot of applied design work which helped me support my creative work. I found a cool balance and access to technologies that I could not have (afford) as an artist, but which I could get (or get access to) as a designer-such as higher end hardware, peripherals and at the time prohibitively expensive software like Adobe After Effects for motion graphics work-and still make my own work on the side. I strategized my studio practice, so it could be funded in part by my design work. I assumed that the two did not have to conflict with each other. That is how I got into new media and expanded practices. I was doing installation work, sound artworks, net art, performances, etc., and I started to meet some very cool people with similar interests in digital media and post studio art practice.

He was brought into the School of Visual Arts at Penn State to create a new media program. For him, much of the current discussion of digital makers culture, which is taking place in ADRI, is not new. What changed now is that traditional media, such as painting, printmaking, and sculpture are existing in an expanded field, incorporating digital processes and tools. Rosas came to Penn State from teaching at the CalArts School of Art, an Art Program which did not really distinguish between studio art disciplines. He stated that "because over there it is not really a thing, CalArts was a great place to be. I was able to wear many hats and not be told that I couldn't or shouldn't." In the 1990s, new media kind of blew up and everybody started scrambling to start programs. He observed that:

By 2001, Penn State was kind of late in the game on creating a digital major. They had some courses in the books, but they hadn't yet developed a curriculum, nor fully integrated digital studio courses into existing areas in the school and college. For me, it was a great opportunity to develop an integrated digital arts curriculum (with the support of my colleagues) and to advocate for and help shape the identity of our digital art and media design programs in the school and college. 
Rosas' inclination for the ephemeral continues to shape his approach to both art and design, and it underlines a practice that is unsettled, disruptive and on the edge.

I guess I am more interested in work that is moving or in flux. I often reflect back on a piece by my mentor at Cranbrook Steve Murakishi (whose work first attracted me to the program) that consisted of two words "OBSOLETE" and "never" with OBSOLETE in large orange formed plastic sign letting on a gallery wall that for some reason has always stuck with me. You are always on the cutting edge of becoming obsolete. In new media, technological and even professional obsolescence can become an unnerving reality. For me, I have had to become very comfortable being uncomfortable. Most everything I do is ephemeral, fleeting or passing, it is in the moment and then displaced. When I look at the work I did a few years ago I can often date it by the primitiveness or latent imprint left by the technologies that were available and the emerging discourse that the work was responding or reacting to. Thus, I have come to expect and even embrace what I consider to be the 'impending obsolescence' of many of the materials and works I produce. In many ways, this perceived notion of an ever progressing "impending obsolescence' in professional practice most certainly motivates me forward, it motivates me to remain relevant, and it motivates me to never 'become' obsolete.

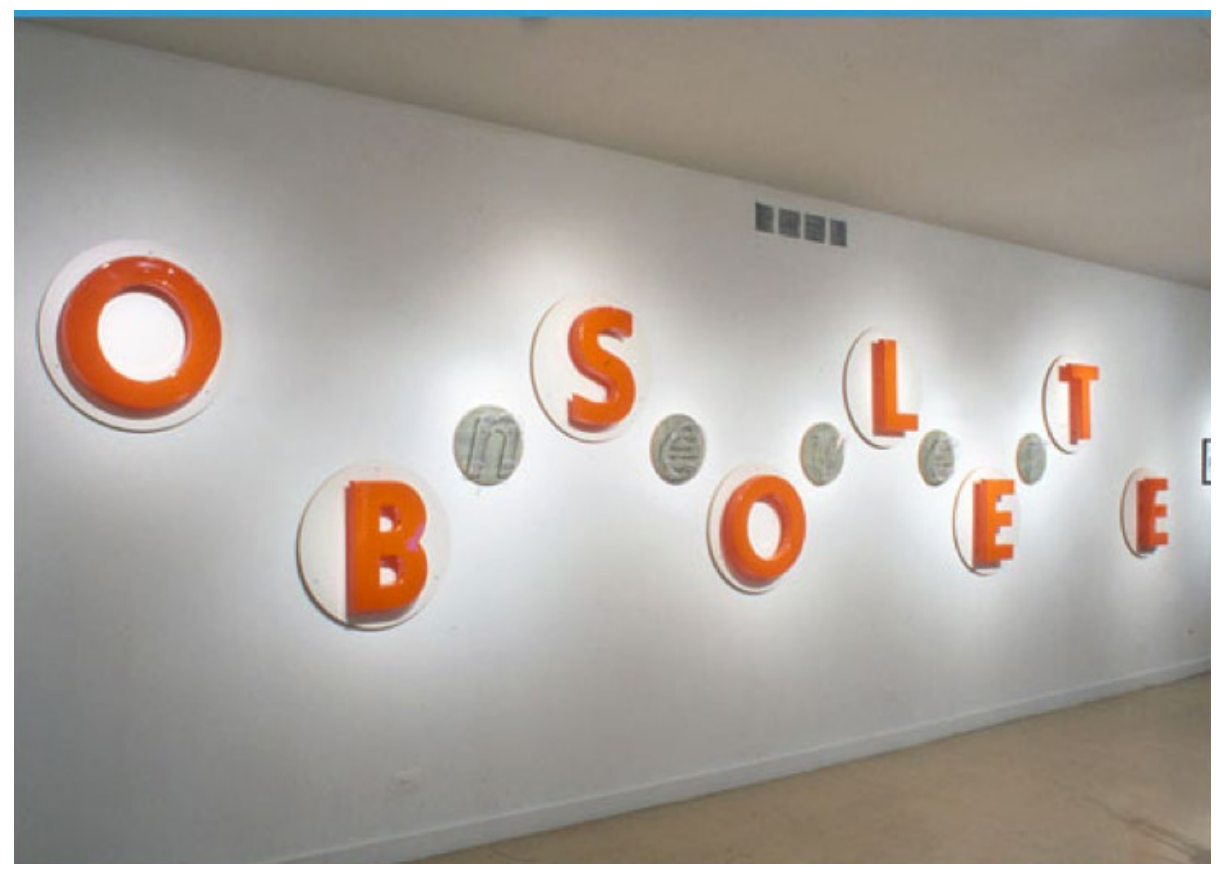

Fig 8. Steve Murakishi, installation..... [needs caption] 
For the most part, he has never been particularly interested in claiming or relying upon any particular medium, nor has he been overly concerned with formal object-making, as much as he has been intrigued by sustained, conceptually-driven investigations of the interplay and power-dynamics at the intersection of media and culture. This interplay and the conceptualization of media frameworks, access, transmission, and interactions have in many ways afforded him a liminal space from which to experiment within new media, particularly digital media authoring and publishing practice, thus enabling him to use-misuse, that is, to converge, engage, and/or disrupt forms through the utilization and leveraging of technology and new media related critical discourse.

And how could this rich experience not be reflected in his teaching? In the School of Visual Arts, Rosas is loved by his students, especially because he challenges them to think critically while giving them room to explore for themselves. He opens possibilities for students who arrive at the University with naïve notions about media, and justifiable concerns about the job market and career opportunities. In the Digital Arts and Media Design program, they develop technical and conceptual skills while being encouraged to think independently, to learn from each other by collaborating in open-ended projects, in sum, to engage with media as a medium and to consider their generative possibilities. Some end up approaching technology by engaging with issues of obsolescence and uncertainty, therefore, incorporating a more critical and disruptive design edge.

1 http://news.psu.edu/story/464878/2017/04/25/arts-and-entertainment/students-create-digital-game-raise-landmine-awareness

2 http://artjournal.collegeart.org/?p=9844

3 David Labaree "Public Goods, Private Goods: The American Struggle over Educational Goals," American Educational Research Journal 34, no. 1 (1997): 39-81. In relation to Education and Democracy, see the classic 1970 Paulo Freire's book Pedagogy of the Oppressed, in which he proposes a problem-posing education as a method of teaching that emphasizes critical thinking for the purpose of liberation. Freire used problem-posing as an alternative to the banking model of education. 4 This is the line of inquiry of the forthcoming German exhibition project, Das Neue Alphabet (2019-2021) at the Haus der Kulturen der Welt (HKW), e-flux, May 7, 2018.

5 Eduardo Navas, "The Influence of Non-places in the Concept of Latin America," Errata \#3, Revista de Artes Visuales, December 2010, Mexico City. 